\title{
FLORIDA GROUND-WATER QUALITY
}

\author{
By George A. Irwin, U.S. Geological Survey \\ and
}

Jacqueline L. Bonds, Florida Department of Environmental Regulation

U.S. Geological Survey Open-File Report 87-0719 


\section{DEPARTMENT OF THE INTERIOR}

DONALD PAUL HODEL, Secretary

\section{U.S. GEOLOGICAL SURVEY}

Dallas L. Peck, Director

For additional information:

Chief Hydrologist

U.S. Geological Survey

407 National Center

Reston, VA 22092
For sale by:

U.S. Geological Survey

Books and Open-File Reports Section Federal Center

Box 25425

Denver, Colorado 80225

Use of trade names in this report is for descriptive purposes only and does not constitute endorsement by the U.S. Geological Survey 


\section{FOREWORD}

This report contains summary information on ground-water quality in one of the 50 States, Puerto Rico, the Virgin Islands, or the Trust Territories of the Pacific Islands, Saipan, Guam, and American Samoa. The material is extracted from the manuscript of the 1986 National Water Summary, and with the exception of the illustrations, which will be reproduced in multi-color in the 1986 National Water Summary, the format and content of this report is identical to the State ground-water-quality descriptions to be published in the 1986 National Water Summary. Release of this information before formal publication in the 1986 National Water Summary permits the earliest access by the public. 


\section{Contents}

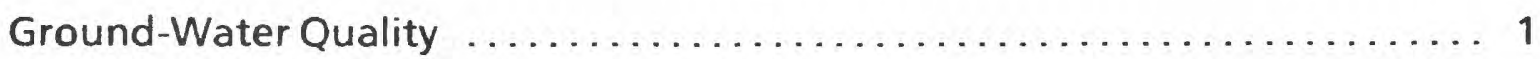

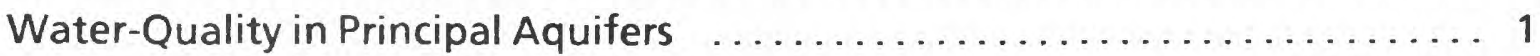

Background Water Quality $\ldots \ldots \ldots \ldots \ldots \ldots \ldots \ldots \ldots \ldots \ldots \ldots \ldots$

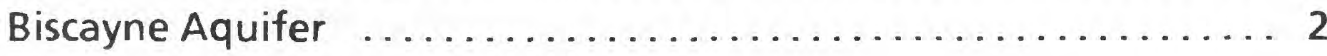

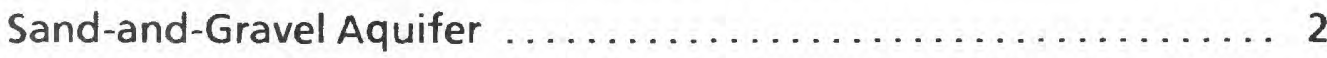

Surficial and Intermediate Aquifers $\ldots \ldots \ldots \ldots \ldots \ldots \ldots \ldots \ldots$

Floridan Aquifer System ........................... 2

Effects of Land Use on Water Quality $\ldots \ldots \ldots \ldots \ldots \ldots \ldots \ldots \ldots \ldots \ldots$

Hazardous-Waste Sites .......................... 3

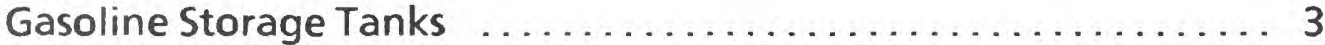

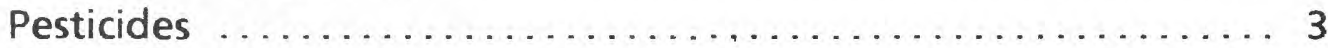

Municipal Landfills ............................... 3

Organic Compounds ........................... 4

Potential for Water-Quality Changes $\ldots \ldots \ldots \ldots \ldots \ldots \ldots \ldots \ldots$

Ground-Water-Quality Management .................... 4

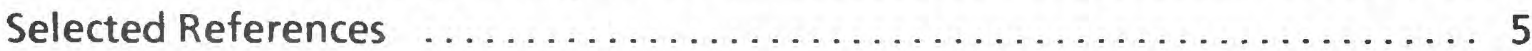

Illustrations

Figure 1.--Selected geographic feature and 1985 population distribution in Florida.

Figure 2.--Principal aquifers and related water-quality data in Florida.

7

Figure 3.--Selected waste sites and ground-water quality information in Florida. 


\section{FLORIDA Ground-Water Quality}

Florida's population in 1980 was about 9.7 million and currently (1986) is increasing at a rate of about 6,000 persons per week. Most major population centers are in south and central Florida (fig. 1). As population increases, so do the demands for water supply and waste assimilation.

Florida has abundant ground-water resources. Large quantities of potable water are obtainable from each of the principal aquifers in most areas of the State (fig. 2). Because of its abundance and availability, ground water is the principal source of freshwater for public-supply, rural, and industrial uses and is the source for about half of the water used for irrigation. More than one-half of the $7,300 \mathrm{Mgal} / \mathrm{d}$ (million gallons per day) of freshwater used in Florida for all purposes comes from ground-water sources (Leach, 1983), and about 90 percent of Florida's population depends on ground water for drinking water.

Potential sources of ground-water contamination are numerous in Florida. Some of these sources include 6,000 surface impoundments for waste disposal; 9,600 drainage wells; 60,000 underground gasoline storage tanks; 800 municipal landfills; more than 400 potential hazardous-waste sites; and the 60,000 -per-year increase in septic tanks. Perhaps as many as one-fourth of Florida's 300 active municipal landfills and almost half of the hazardous-waste sites are suspected of degrading the quality of ground water (fig. 3 ). Florida is ranked second in pesticide application in the Nation, but thirty-third in planted acreage. Currently, some 9,500 pesticide formulations are used in the State (Pickrell Stoddard, Florida Department of Environmental Regulation, oral commun., 1987). They comprise various combinations of more than 600 active ingredients, of which more than 45 are "restricted-use pesticides."

Regionally, the inorganic quality of water from the principal aquifers used for public supply does not exceed State primary drinking-water standards. In many parts of the State, however, ground-water supplies commonly exceed secondary drinking-water standards. For example, a recent sampling of 120 major public supplies serving about 30 percent of the State's population indicated no violations of primary drinking-water standards. However, the concentration of dissolved solids exceeded the secondary standard of $500 \mathrm{mg} / \mathrm{L}$ (milligrams per liter) in about 20 percent of the supplies (Irwin and others, 1985).

Data on the organic quality of water from the State's principal aquifers are limited; nevertheless, occasional incidences of organic contamination of ground water that may affect human health and welfare are a reality in Florida. Irwin and others (1985) indicated that six public supplies contained some trace amounts of organic contamination, but none of the contamination exceeded drinking-water standards. During the last few years, the ground water used for public supplies in both Belleview and Stuart (fig. 1A) was contaminated by gasoline (Florida Department of Environmental Regulation, 1986a). The contamination at Belleview was extensive enough to result in abandonment of the city's well field. Contamination of ground water used for public supply from industrial organic compounds, primarily trichloroethylene and vinyl chloride, also has been discovered in Pensacola and several southeastern Florida coastal communities (G.M. Dykes, Florida Department of Environmental Regulation, oral commun., 1986). Organic chemicals also have contaminated public-supply wells near Gainesville in Alachua County. The organic pesticide ethylene dibromide (EDB) was identified in more than 1,000 public-supply wells throughout the State's agricultural regions (G.M. Dykes,
Florida Department of Environmental Regulation written commun., 1986). Although water contaminated with EDB is usually treatable with granular activated carbon, the widespread contamination illustrates the vulnerability of ground-water resources in Florida. State agencies have identified 413 potential hazardous-waste sites; of these, 86 are at various stages of permitting and monitoring pursuant to the Federal Resource Conservation and Recovery Act (RCRA) of 1976, the Florida Resources Recovery and Management Act of 1980, and the Florida Water Quality Assurance Act of 1983. Preliminary monitoring indicates that about 10 percent of the RCRA land-disposal sites have contaminated ground water. There are 39 class I (U.S. Environmental Protection Agency, 1984) Underground Injection Control (Uic) waste-disposal well sites in Florida -7 industrial and 32 municipal (Florida Department of Environmental Regulation, 1985b). Florida has 39 hazardous-waste sites that have been either proposed or included in the National Priorities List (NPL) (Superfund) of hazardous-waste sites compiled by the U.S. Environmental Protection Agency (1986c). Groundwater contamination has been confirmed at 32 of these "Superfund" sites, and site remedial action is being initiated under the Comprehensive Environmental Response, Compensation, and Liability Act (CERCLA) of 1980. At four of the CERCLA (Superfund) sites, the U.S. Environmental Protection Agency (EPA) has invoked "immediate removal" cleanup action under CERCLA. In addition there are $\mathbf{2 0}$ waste sites at 4 federal facilities in Florida under the U.S. Department of Defense Installation Restoration Program (IRP).

Statewide, 70 hazardous-waste sites, which include selected CERCLA, RCRA, and State Action (part of Florida Resources Recovery and Management Act of 1980) sites, are undergoing cleanup. The majority, or 48 sites, are being cleaned by the responsible party, and the remaining 22 sites are being cleaned with government funds- 15 with State funds (Florida Department of Environmental Regulation, 1985c).

\section{WATER QUALITY IN PRINCIPAL AQUIFERS}

The principal aquifers in Florida are the Biscayne aquifer, the sand-and-gravel aquifer, the surficial and intermediate aquifers, and the Floridan aquifer system (fig. 2A). The hydrogeologic characteristics of these aquifers have been described previously (U.S. Geological Survey, 1985, p. 173-178).

Water in the sand-and-gravel aquifer is the least mineralized, with concentrations of dissolved solids exceeding $100 \mathrm{mg} / \mathrm{L}$ generally only in coastal areas where saltwater intrusion occurs. Except for water in the sand-and-gravel aquifer, ground water in Florida is classified as hard to very hard. Concentrations of nitrate and fluoride in Florida's ground water are considerably smaller than the maximum prescribed by State drinking-water standards. Iron, however, is common in undesirable concentrations throughout Florida, particularly in water from the Biscayne and surficial aquifers.

\section{BACKGROUND WATER QUALITY}

A graphic summary of selected water-quality variables compiled from the U.S. Geological Survey's National Water Data Storage and Retrieval System (WATSTORE) is presented in figure $2 B$. The summary is based on dissolved solids, hardness, nitrate (as nitrogen), sodium, and iron analyses of water samples collected from 1970 to 1986 from the principal aquifers in Florida. Percen- 
tiles of these variables are compared to national standards that specify the maximum concentration or level of a contaminant in drinking-water supply as established by the U.S. Environmental Protection Agency (1986a,b). The primary maximum contaminant level standards are health related and are legally enforceable. The secondary maximum contaminant level standards apply to esthetic qualities and are recommended guidelines. The primary drinkingwater standards include a maximum concentration of $10 \mathrm{mg} / \mathrm{L}$ nitrate (as nitrogen), and the secondary drinking-water standards include maximum concentrations of $500 \mathrm{mg} / \mathrm{L}$ dissolved solids and $300 \mu \mathrm{g} / \mathrm{L}$ (micrograms per liter) iron. For these variables, State drinkingwater standards are the same as the national standards.

\section{Biscayne Aquifer}

The Biscayne aquifer (fig. 2, aquifer 1) underlies all Dade and Broward Counties and parts of Palm Beach and Monroe Counties. The aquifer consists of a very permeable limestone in southern and western Dade County that becomes less permeable in the northern and eastern parts of the county (U.S. Geological Survey, 1985). The Biscayne aquifer has been designated by the EPA as a "sole source" drinking-water supply, with a public-supply withdrawal of about $461 \mathrm{Mgal} / \mathrm{d}$ (Leach, 1983). The aquifer is managed carefully to control saltwater intrusion. Water in the Biscayne aquifer is primarily a calcium bicarbonate type and does not exceed standards for most uses. Concentrations of dissolved solids are smaller than $400 \mathrm{mg} / \mathrm{L}$ in about 90 percent of the samples analyzed, although most water is classified as very hard. Concentrations of nitrate and fluoride are considerably smaller than drinking-water standards, with respective median values of 0.01 and $0.30 \mathrm{mg} / \mathrm{L}$. Iron concentrations in untreated ground water are commonly larger than the secondary drinking-water standard of $300 \mu \mathrm{g} / \mathrm{L}$. Iron is commonly associated with the large natural organic content of the region's ground-water resource. This large natural organic content has contributed to the formation of trihalomethanes during chlorination of public-water supplies.

\section{Sand-and-Gravel Aquifer}

The sand-and-gravel aquifer (fig. 2, aquifer 2 ) is the major source of water supply in the western part of the Florida Panhandle, with a public-supply withdrawal of about $34 \mathrm{Mgal} / \mathrm{d}$ (Leach, 1983). The aquifer thickness exceeds 700 feet in northwestern Escambia County. The aquifer thins to the south and east and pinches out in central Walton County (U.S. Geological Survey, 1985). The major inorganic chemical constituent in water from this aquifer is sodium chloride, with concentrations of dissolved solids smaller than $60 \mathrm{mg} / \mathrm{L}$ in about 75 percent of the aquifer. The water is considered to be soft and suitable for most uses, although safeguards against corrosion may be needed in some instances. Concentrations of sodium, nitrate, and fluoride generally do not exceed the drinkingwater standards. Iron concentrations in the ground water, however, may exceed the secondary drinking-water standard of $300 \mu \mathrm{g} / \mathrm{L}$ in about 10 percent of the samples analyzed. Near the coast, saltwater intrusion can occur.

\section{Surficial and Intermediate Aquifers}

Surficial aquifers (fig. 2, aquifer 3 ) are present in much of the east coastal and south-central parts of Florida. These aquifers are little used where more plentiful supplies are available from deeper aquifers that contain potable water. Statewide, withdrawal for public supply is estimated at about 80 to $90 \mathrm{Mgal} / \mathrm{d}$ (Leach, 1983). The surficial aquifers consist of sand and shell with minor limestone beds. These aquifers are used most intensively for public supply in the area southwest of Lake Okeechobee and in scattered towns along the east coast (U.S. Geological Survey, 1985). In general, the major inorganic chemical composition of water from the surficial aquifers is calcium bicarbonate. Concentrations of dissolved solids generally are smaller than about $1,200 \mathrm{mg} / \mathrm{L}$ in 90 percent of the samples analyzed; however, concentrations of several thousand milligrams per liter are not uncommon in some areas. saltwater intrusion and flowing artesian wells that tap deeper, saline aquifers can greatly affect salinity in the surficial aquifers. The water is considered to be hard to very hard. On the average, concentrations of nitrate, fluoride, chloride, and dissolved solids do not exceed drinking-water standards. Iron concentrations exceed the standards in more than half of the samples analyzed.

In southern Florida and along the eastern part of peninsular Florida, one or more aquifers are present between the local surficial aquifer and the underlying Floridan aquifer system; these are informally referred to as intermediate aquifers (fig. 2, aquifer 4) (U.S. Geological Survey, 1985). The rocks that contain the intermediate aquifers are mainly limestone and shell beds interbedded with sand and clay. Intermediate aquifers are an important source of water for public supply and irrigation in coastal southwestern Florida from about Sarasota County to Lee County where the underlying Floridan aquifer system contains nonpotable water (U.S. Geological Survey, 1985). The public-supply withdrawal is estimated at about $156 \mathrm{Mgal} / \mathrm{d}$ (Leach, 1983). The major inorganic chemical composition of water from the intermediate aquifers generally is a mixed calcium magnesium bicarbonate, with concentrations of dissolved solids of about $550 \mathrm{mg} / \mathrm{L}$ or larger in about 50 percent of the samples analyzed. The water from these aquifers is considered to be hard to very hard. Nitrate, fluoride, and iron concentrations generally do not exceed drinking-water standards, but sodium, chloride, and dissolved solids commonly do. saltwater intrusion and upward movement of saline water from the deeper aquifer commonly result in unsuitable water quality for most uses in many areas.

\section{Floridan Aquifer System}

The Floridan aquifer system (fig. 2, aquifer 5), one of the most productive sources of ground water in the United States, extends across all of Florida, southern Georgia, and adjoining parts of Alabama and South Carolina. The Floridan is the lowermost part of the ground-water reservoir in Florida. It consists of as much as 3,500 feet of limestone and dolomite beds that are interconnected hydraulically to differing degrees (U.S. Geological Survey, 1985).

Total pumpage from the aquifer system in Florida exceeds 2,000 Mgal/d (P.W. Bush, U.S. Geological Survey, written commun., 1984) and the public-supply withdrawal is about $460 \mathrm{Mgal} / \mathrm{d}$ (Leach, 1983). Many public-supply systems tap the Floridan aquifer system, including most major cities in the northern half of the State. The Floridan also is a major source of water for industrial, irrigation, and rural uses.

The major inorganic chemical constituent in the water is calcium bicarbonate, with a concentration of dissolved solids smaller than $500 \mathrm{mg} / \mathrm{L}$ in about 90 percent of the samples analyzed. Although the water tends to be hard, it generally does not exceed the drinking-water standards for nitrate, fluoride, sodium, and chloride in at least 75 percent of the samples analyzed. Iron may exceed the standard, but probably not in more than 10 percent of the water-quality analyses.

\section{EFFECTS OF LAND USE ON WATER QUALITY}

Florida's unique hydrogeologic features of a thin soil layer, high water table, porous limestone, and large amounts of rainfall, coupled with its rapid population growth, result in a ground-water resource extremely vulnerable to contamination. Numerous structures resulting from human activities throughout Florida have the potential to contribute to ground-water contamination. There are tens of thousands of potential point sources such as surface-water 
impoundments, drainage wells, underground storage tanks, flowing saline artesian wells, hazardous-waste sites, powerplants, landfills, and cattle and dairy feedlots. Similarly, there are numerous septic tanks and urban and industrial-commercial areas that may recharge water of undesirable quality. Nonpoint sources, which have vast potential for contributory ground-water contamination, include coastal saltwater bodies, agricultural and silvicultural practices, and mining.

The distribution of selected types of waste-disposal sites and occurrences of ground-water contamination are shown in figure 3. Figure $3 A 2$ shows the locations of the CERCLA, RCRA, IRP, and UIC sites and figure $3 A 1$ shows a summary by county of potential hazardous-waste sites identified by the State. Reported cases of recent ground-water contamination summarized by county are shown in figure $3 B$. In many cases included in this summary, the principal aquifer was not directly affected; further, not all cases posed a significant threat to human health and welfare. The reported cases mainly represent recent information gathered from special State and Federal studies on drinking-water supplies, hazardous and nonhazardous waste-site monitoring, and underground storage tanks. Figure $3 B$ is a very general portrayal and likely does not represent all recent contamination cases of ground water or supply wells. In particular, figure $3 B$ does not include bacteriological data collected by the numerous county and local health agencies. Figure $3 C$ shows the distribution of active and inactive municipal landfills in Florida.

A brief overview of some human activities affecting the environmental integrity of Florida's ground-water resource is presented below.

\section{Hazardous-Waste Sites}

As of February 1986, 413 potential hazardous-waste sites have been identified in Florida (Florida Department of Environmental Regulation, 1986b). Currently, six counties have more than 20 sites-Dade (48), Hillsborough (46), Duval (41), Broward (40), Polk (38), and Palm Beach (23) (fig. 3A1). Statewide, 185 of these sites had some type of water or soil contamination and 84 additional sites were suspected of contamination. Ground-water contamination was confirmed at 156 sites. Nearby supply wells at some of these sites have been contaminated, but thorough documentation is not available. Enforcement action requiring contamination assessment and necessary remedial action has been initiated at 118 sites (Florida Department of Environmental Regulation, 1986b).

Some of the more notable hazardous-waste sites are the 39 CERCLA (Superfund) sites (as of May 1986) shown in figure $3 A 2$. Ground-water contamination was confirmed at 32 of these sites and was suspected, but unconfirmed, at the remaining 7 (Florida Department of Environmental Regulation, 1986b). The primary contaminants at most of these sites were a mix of industrial organic solvents. These sites represent disposal of hazardous waste that constitutes a major threat to the quality of underlying ground water. Because of the absence of a significant amount of relatively impermeable surficial material to retard downward movement of contaminants, leakage from many of the sites poses a direct threat to the principal aquifers, particularly in southern and western Florida.

As of September 1985, 160 hazardous-waste sites at 14 facilities in Florida have been identified by the U.S. Department of Defense (DOD) as part of IRP as having potential for contamination. The IRP, established in 1976, parallels the EPA Superfund program under CERCLA. The EPA presently ranks these sites under a hazard ranking system and may include them in the NPL. Of the 160 sites in the program, 8 contained contaminants but did not present a hazard to people or the environment. Twenty sites at 4 facilities (fig. $3 A 2$ ) presented a hazard significant enough to warrant response action in accordance with CERCLA.

\section{Gasoline Storage Tanks}

The Florida Department of Environmental Regulation (1986a) had documented more than 400 instances of ground-water contamination from leaking gasoline pipes or storage tanks as of April 30, 1986. The greatest frequency of gasoline contamination occurred in Dade County ( 77 cases), Broward County (57 cases), and Palm Beach County ( 25 cases) (fig. $3 B$ ). In many of these cases the quality of water in the Biscayne aquifer was directly affected. Statewide, perhaps the most environmentally and financially significant incident was the leaking of 10,000 gal (gallons) of gasoline between October 1979 and March 1980, which contaminated the public-water supply for about 2,000 residents at Belleview (see fig. $1 A$ ). The contamination was extensive enough to result in abandonment of the city's well field. Other gasoline leaks in rural Marion County have caused contamination of about 20 supply wells in the unconfined Floridan aquifer system and are under special study by the Department of Environmental Regulation. A leaky gasoline pipeline in Duval County contaminated 14 wells in the Floridan aquifer system. Another gasoline leak of immediate concern to the State occurred in Cocoa Beach, Brevard County, where between 800 and 1,600 gal of gasoline is floating atop the underlying ground water.

\section{Pesticides}

Pesticide contamination of ground water has become a major environmental issue in Florida. Since 1983, water from more than 1,000 public and private supply wells, primarily in the Floridan aquifer system, have been found to contain levels of the soil fumigant EDB above the State regulation of $0.02 \mu \mathrm{g} / \mathrm{L}$. Statewide, EDB has been detected in 50 community wells, 74 noncommunity wells, and 922 private wells as of May 1986 (G.M. Dykes, Florida Department of Environmental Regulation written commun., 1986). The distribution of EDB was extensive, with detections in ground water in 22 of the 66 counties tested. The most pervasive detections were in Jackson, Lake, Highlands, and Polk Counties (fig. 3B). Although the number of wells sampled per county differed, 10 counties had confirmed EDB in 10 percent or more of the wells tested. The State has taken, or assisted in, remedial measures using granular activated carbon; nonetheless, perhaps as many as 60,000 people were at least temporarily affected (G.M. Dykes, Florida Department of Environmental Regulation oral commun., 1986).

Aldicarb (Temik) has also been detected in ground water at seven agricultural study sites in Hillsborough, Martin, Polk, St. John, Seminole, and Volusia Counties. At one of the Polk County sites, aldicarb residues appeared to have migrated 300 feet laterally from the point of application (Florida Department of Environmental Regulation, 1984b).

Other recent studies have indicated trace concentrations of pesticides in 3 of 91 major public supplies in Florida (Irwin and others, 1985) and in shallow ground water near treatment-plant spray fields (Pruitt and others, 1985). None of these detections, however, exceeded State drinking-water standards. A reconnaissance of about 40 large springs (J.B. Pruitt, U.S. Geological Survey, written commun., 1986) indicated EDB in one spring in Orange County in concentrations exceeding the State drinking-water regulation of 0.02 $\mu \mathrm{g} / \mathrm{L}$. Pesticide compounds also are common contaminants near landfills.

\section{Municipal Landfills}

The State has about 300 active and 500 inactive landfill sites (fig. $3 C$ ). Most of the landfills are unlined. Six of Florida's CERCLA (Superfund) sites are landfills, and all have contaminated the underlying ground water. Three in southeastern Florida have directly contaminated the Biscayne aquifer. More than 50 additional land- 
fills likely have contributed to ground-water contamination and have been identified for remedial action by the State. The statewide extent of public-supply well contamination from landfills presently is poorly documented. A recent landfill study concluded that "the potential for ground-water pollution from landfills is severe in Florida at the present time and will continue to get worse until regulations and practices catch up to existing technology" (Miller and others, 1985, p. viii).

\section{Organic Compounds}

Incidences of volatile organic compounds (voc), aromatics, and trihalomethane in ground water, particularly in southern Florida, have become an issue of concern. A recent study of public supplies from the Biscayne aquifer in Broward, Dade, and Palm Beach Counties reported that four supplies serving about 290,000 people indicated voc concentrations that slightly exceeded Florida drinkingwater standards (Vincent, 1984). The primary compounds detected were trichloroethylene and vinyl chloride, which have maximum contaminant level concentrations of 3 and $1 \mu \mathrm{g} / \mathrm{L}$, respectively. In all, 27 public supplies had detectable amounts of voc, but at 23 of them the concentration did not exceed the standards. The report also indicated that the overall voc quality of the three-county area has improved since 1982 when 1.3 million people were receiving drinking water with voc exceeding State regulations. Additional study of 150 industrial facilities to identify possible sources of voc contamination in the area is now underway. Recent incidents of voc contamination in ground-water supplies have also occurred in other parts of the State. Several city supply wells for Pensacola and Gainesville were closed temporarily (1985-86) because of voc contamination.

Public water-supply data collected as part of the EPA's national organics reconnaissance, the national organic monitoring survey, and the ground-water systems survey, indicate that 25 to 30 percent of the ground-water supplies tested in Florida may have some contamination from $v O C$ and other synthetic organic compounds (G.M. Dykes, Florida Department of Environmental Regulation written commun., 1986). Further, 35 percent of the community systems supplying a population of 10,000 or more is likely to have detectable levels of trihalomethanes after chlorination.

\section{POTENTIAL FOR WATER-QUALITY ChANGES}

Currently, Florida is only moderately industrialized, but it has one of the fastest growing populations. Future population growth is projected to be most intensive in coastal-urban areas, although central and northern urban areas will also be affected (fig. $1 B$ ). Increased development in coastal areas may result in saltwaterintrusion problems, and agricultural stresses of today likely will give way to future water-quality effects associated with increased urban, commercial, and industrial development.

In many areas of Florida, the present degradation of water has occurred only in surficial deposits and not in the deeper principal aquifer, but downward movement of contamination is a possible threat. In other hydrogeologic settings such as in southeastern Florida, however, the principal aquifer has been directly contaminated.

\section{GROUND-WATER-QUALITY MANAGEMENT}

The Florida Department of Environmental Regulation, created by the Florida Environmental Reorganization Act of 1975, is the primary State agency responsible for water-quality management. The Department's activities are funded by State general revenue and Federal grants. The Department has regional offices throughout the State. The Florida Department of Natural Resources has jurisdiction over Class II Oil and Gas deep wells as specified under the UIC program. The Florida Department of Health and
Rehabilitative Services has jurisdiction over the use of water withdrawn from private wells as mandated by the U.S. Environmental Protection Agency (1986a) and the Florida Department of Environmental Regulation (1985d). The Department of Environmental Regulation has jurisdiction over public supplies. The Department of Health and Rehabilitative Services also has jurisdiction over the regulation of domestic septic tanks. The Florida Department of Community Affairs is involved in the Development of Regional Impact documents, which in many instances involve water-quality issues. In addition to State agencies, the local county health departments and pollution control boards are involved to varying extents in water-quality issues. These program regulations and activities may occasionally overlap with those of the Department of Environmental Regulation. The local agency's regulations, however, may not be less stringent than the State's regulations.

Water-quantity management, under the Florida Water Resources Act of 1972, is the primary responsibility of the five Water Management Districts funded by property taxation and covering specifically delineated areas of the State. The five districts are the Northwest Florida Water Management District, the St. Johns River Water Management District, the South Florida Water Management District, the Southwest Florida Water Management District, and the Suwannee River Water Management District.

The Department of Environmental Regulation has assumed primacy for the protection of ground water mandated by Federal legislation. The appropriate State legislation primarily includes the Environmental Control Act of 1972, the Florida Environmental Reorganization Act of 1975, the Florida Resource Recovery and Management Act of 1980, and the Water Quality Assurance Act of 1983. New legislation mandated the State Underground Petroleum Environmental Response (SUPER) Act of 1986, which became effective in July 1986 and addresses the problem of leaking underground storage tanks.

A statewide water policy designed to bring a more consistent approach to water-management practices was adopted in 1981. The policy is designed to coordinate the water quality and quantity issues and to encourage preservation of natural systems through use of nonstructural water-management techniques. Florida has a comprehensive ground-water rule that became effective in 1983. Primarily under Chapters 17-3, 17-4, and 17-22 of the Florida Administrative Code, the State expanded ground-water classification, applied secondary drinking-water standards to Florida's aquifers, added minimum water-quality criteria, created more restrictive zones of discharge, encouraged recycling of wastewaters that are compatible with receiving ground water, and increased the authority of the Department of Environmental Regulation to prevent the introduction of dangerous toxic materials into drinkingwater supplies.

The Water Quality Assurance Act of 1983 established the Department of Environmental Regulation as the central repository for water-resources data and authorized the Department to design an extensive ground-water monitoring network, which ultimately may include as many as 2,500 wells. A primary intent of this network will be to provide data useful to protect potable supplies from contamination. Much of this activity will be in cooperation with the U.S. Geological Survey and the five Water Management Districts. One aspect of the Water Quality Assurance Trust Act, established in 1983, was to coordinate emergency response operations and to clean or provide corrective action at hazardous-waste sites that threaten or have contaminated ground waters. Additional significant aspects of Florida's ground-water protection program include the Department's storage tank program designed to assure that above- and below-ground tanks are installed properly and do not leak gasoline or other toxic materials that can cause groundwater contamination. The Department of Environmental Regulation also has an underground injection-control regulatory program 
that applies specifically to injection wells. The program is designed to ensure that wastes injected underground are injected into the proper geologic layer and depth and that they stay confined in that area. The Department's ground-water monitoring and CERCLA site screening programs call for sampling of suspected contaminated ground water throughout the State.

The ultimate authority to preserve the State's environmental integrity and water quality is based on regulatory programs for permitting and enforcement. The State's regulatory program is designed to merge citizen complaints, departmental investigations, water analysis, and a variety of planning and management programs. Permitting protocol is the major tool used in the regulatory program and is administered chiefly through district offices of the Department of Environmental Regulation located throughout the State. Illegal pollution, operating without a permit, or violating permit conditions may, under Florida law, be grounds for enforcement action by the Department. Legal action, with criminal penalties or fines of as much as $\$ 10,000$ a day for each separate violation, may be instituted. If hazardous-waste rules are violated. penalties can include fines of as much as $\$ 50,000$ a day for each violation, in addition to any corrective or remedial action that may be required to halt illegal discharges.

\section{SELECTED REFERENCES}

Association of Ground Water Scientists and Engineers, 1985, The impact of regional variations on hydrogeologic investigations: National Water Well Association Annual Meeting, Baltimore, 1985, Proceedings, $30 \mathrm{p}$.

Bush, P.W., 1982, Predevelopment flow in the Tertiary limestone aquifer, southeastern United States-A regional analysis from digital modeling: U.S. Geological Survey Water-Resources Investigations Report $82-905,41 \mathrm{p}$.

Florida Department of Environmental Regulation, 1972, Environmental Control Act: Florida Statutes, Chapter 403.

1975, Florida Environmental Reorganization Act: Florida Statutes, Chapter 403.801.

1980, Resources recovery and management: Chapter 17-7 in Florida Administrative Code.

1983a, Water Quality Assurance Act: Florida Law. Chapter 83-310.

1983b, Water quality standards: Chapter 17-3 in Florida Administrative Code.

1984a, Permits: Chapter 17-4 in Florida Administrative Code. 1984b, Summary of aldicarb studies: Pesticide Review Section, August $1984,87 \mathrm{p}$.

1985a, Directory of solid waste facilities: Solid Waste Management Program, October 1985, 87 p.

1985b, Florida class I and major class V injection well data sheets: Groundwater Section, May 1985, 235 p.

1985c, Groundwater, a guide booklet to Florida's hidden water supply: Office of Public Information, July 1985, 16 p.

1985d, Public drinking water systems: Chapter 17-22 in Florida Administrative Code.

1986a, Florida sites list, petroleum contamination incidents: Bureau of Operations, April 1986, 82 p. 1986b, The sites list, summary status report, January I, 1986June 30, 1986: Bureau of Operations, February 1986, 155 p.

Franks, B.J., ed., 1982, Principal aquifers in Florida: U.S. Geological Survey Water-Resources Investigations Open-File Report 82-255, 4 sheets.

Irwin, G.A., Kirkland, R.T., and Pruitt, J.B., 1985, Quality of ground water used for public supply in Florida, 1983-84: U.S. Geological Survey Open-File Report 84-804, 1 sheet.

Leach, S.D., 1983, Source, use, and disposition of water in Florida, 1980: U.S. Geological Survey Water-Resources Investigations Report $82-4090,337 \mathrm{p}$.

Miller, W.L., Reese, John, Lusk, Richard, and others, 1985, An investigation of solid waste landfill closure in Florida: University of Florida, Department of Environmental Engineering Science, College of Engineering, $176 \mathrm{p}$.

Pruitt, J.B., Troutman, D.E., and Irwin, G.A., 1985, Reconnaissance of selected organic contaminants in effluent and ground water at 15 municipal wastewater treatment plants in Florida, 1983-84: U.S. Geological Survey Water-Resources Investigations Report 85-4167, $29 \mathrm{p}$.

Solley, W.B., Chase, E.B., and Mann, W.B., IV, 1983, Estimated use of water in the United States in 1980: U.S. Geological Survey Circular $1001,56 \mathrm{p}$.

U.S. Department of Defense, 1986, Status of the Department of Defense Installation Restoration Program-Information Paper: Washington, D.C., U.S. Department of Defense, Office of the Assistant Secretary of Defense (Acquisition and Logistics), Environmental Policy Directorate, February, $35 \mathrm{p}$.

U.S. Environmental Protection Agency, 1976, Resource Conservation and Recovery Act (RCRA): 42USC6901 enacted as Public Law 94-580, October 21, 1976.

1980, Comprehensive Environmental Response, Compensation, and Liability ACt (CERCLA): 42USC9601 enacted as Public Law 96-510, December 11, 1980.

1984, Classification of injection wells (section 146.5 of subpart A of part 146. Underground injection control program: criteria and standards): U.S. Code of Federal Regulations, Title 40. Part 146, July 1, 1984, p. 371-372.

1986a, Maximum contaminant levels (subpart B of Part 141, National interim primary drinking-water regulations): U.S. Code of Federal Regulations, Title 40, parts 100 to 149 , revised July 1, 1986, p. 524-528.

1986b, Secondary maximum contaminant levels (section 143.3 of Part 143, National secondary drinking-water regulations): U.S. Code of Federal Regulations, Title 40, parts 100 to 149, revised July I, 1986, p. 587-590.

1986c, Amendment to National Oil and Hazardous Substances Contingency Plan; national priorities list, final rule and proposed rule: Federal Register, v. 51, no. 111, June 10, 1986, p. 21053-21112. 1986d, National priorities list fact book-June 1986: U.S. Environmental Protection Agency, Office of Emergency and Remedial Response, report HW-7.3, $94 \mathrm{p}$.

U.S. Geological Survey, 1985. National water summary 1984-Hydrologic events, selected water-quality trends, and ground-water resources: U.S. Geological Survey Water-Supply Paper 2275, $467 \mathrm{p}$.

Vincent, J.R., 1984, South Florida drinking water investigation, Broward, Dade, and Palm Beach Counties: U.S. Environmental Protection Agency, EPA-300/1-84-001, 190 p.

Prepared by George A. Irwin, U.S. Geological Survey, and Jacqueline L. Bonds, Florida Department of Environmental Regulation, Tallahassee, Florida 


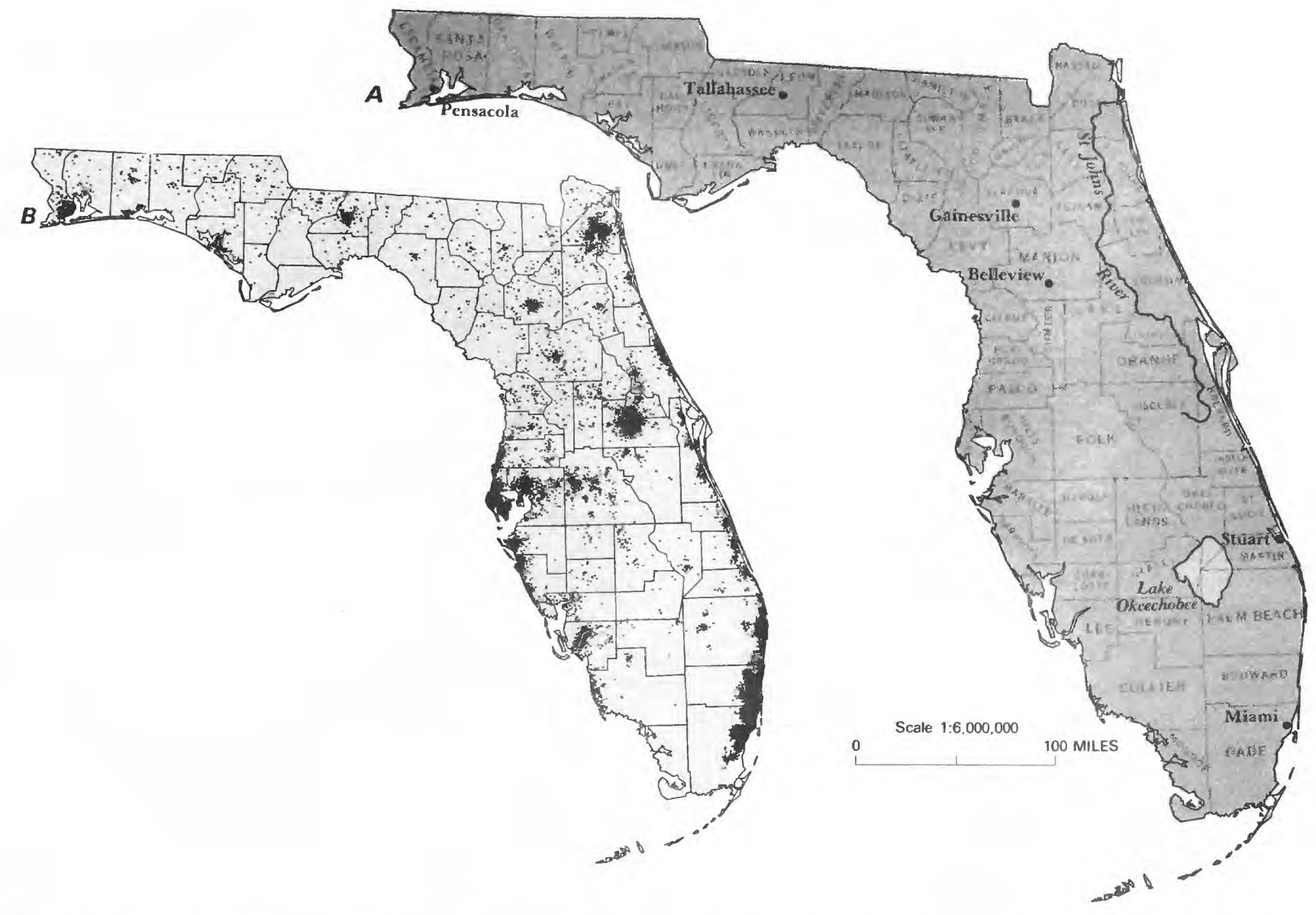

Figure 1. Selected geographic features and 1985 population distribution in Florida. A, Counties, selected cities, and major drainages. B, Population distribution, 1985; each dot on the map represents 1,000 people. (Source: B. Data from U.S. Bureau of the Census 1980 decennial census files, adjusted to the 1985 U.S. Bureau of the Census data for county populations. I 


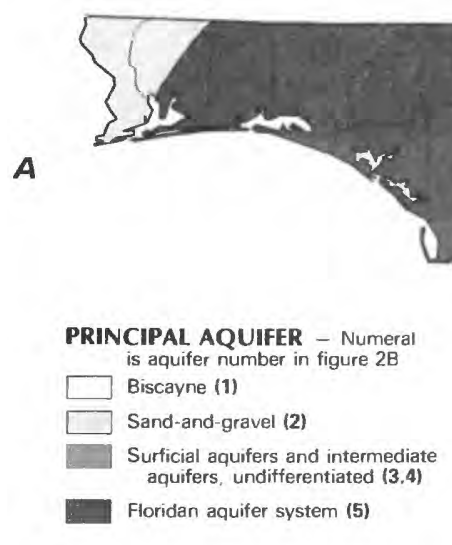

\section{$B$ WATER-QUALITY DATA}

Percentile - Percentage of analyses equal

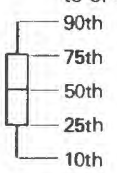

or less than indicated values
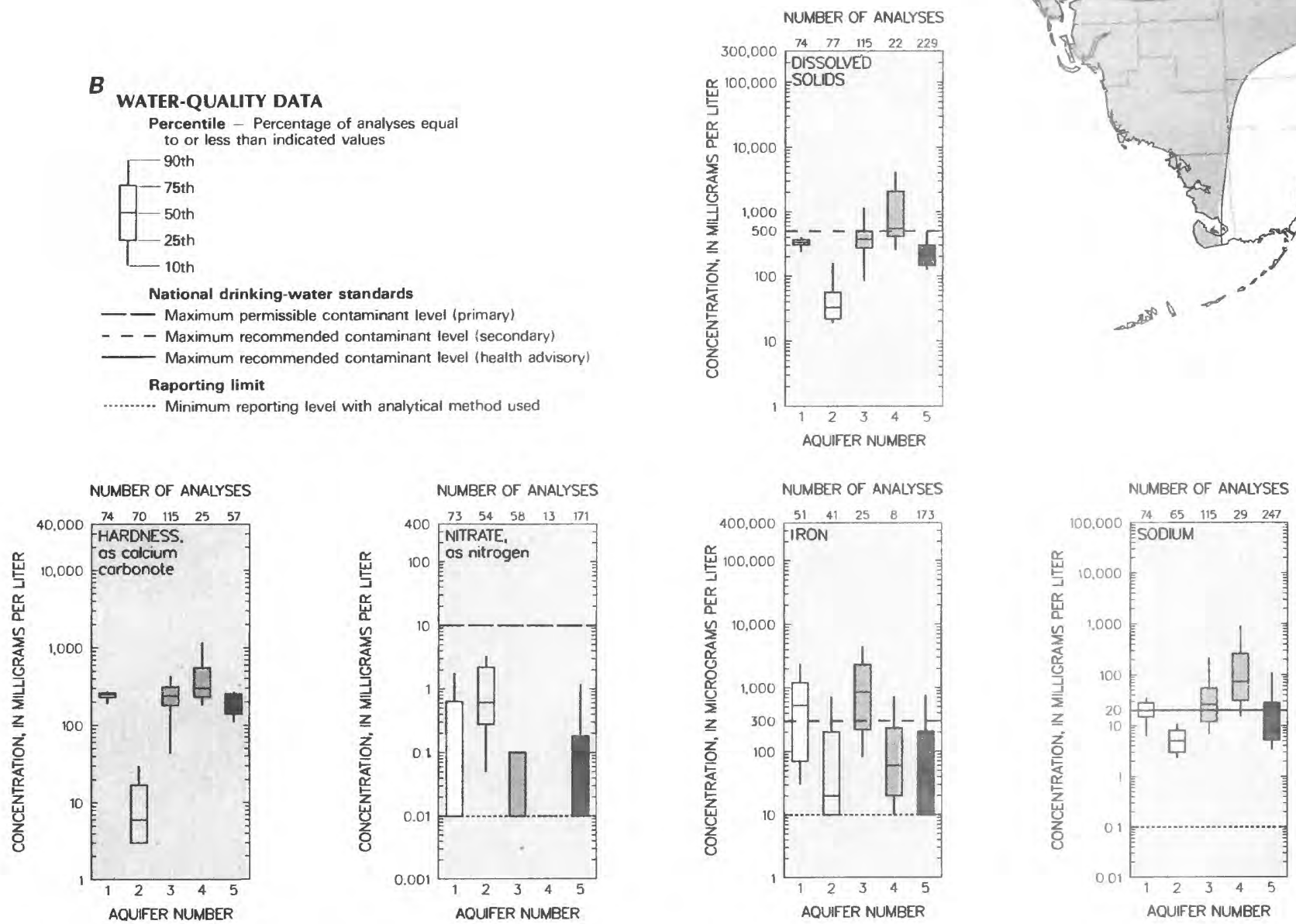

Figure 2. Principal aquifers and related water-quality data in Florida. $A$, Principal aquifers. $B$, Selected water-quality constituents and properties, as of 1970-86. (Sources: A, U.S. Geological Survey, 1985. B. Analyses compiled from U.S. Geological Survey files; national drinking-water standards from U.S. Environmental Protection Agency, 1986a, b.) 

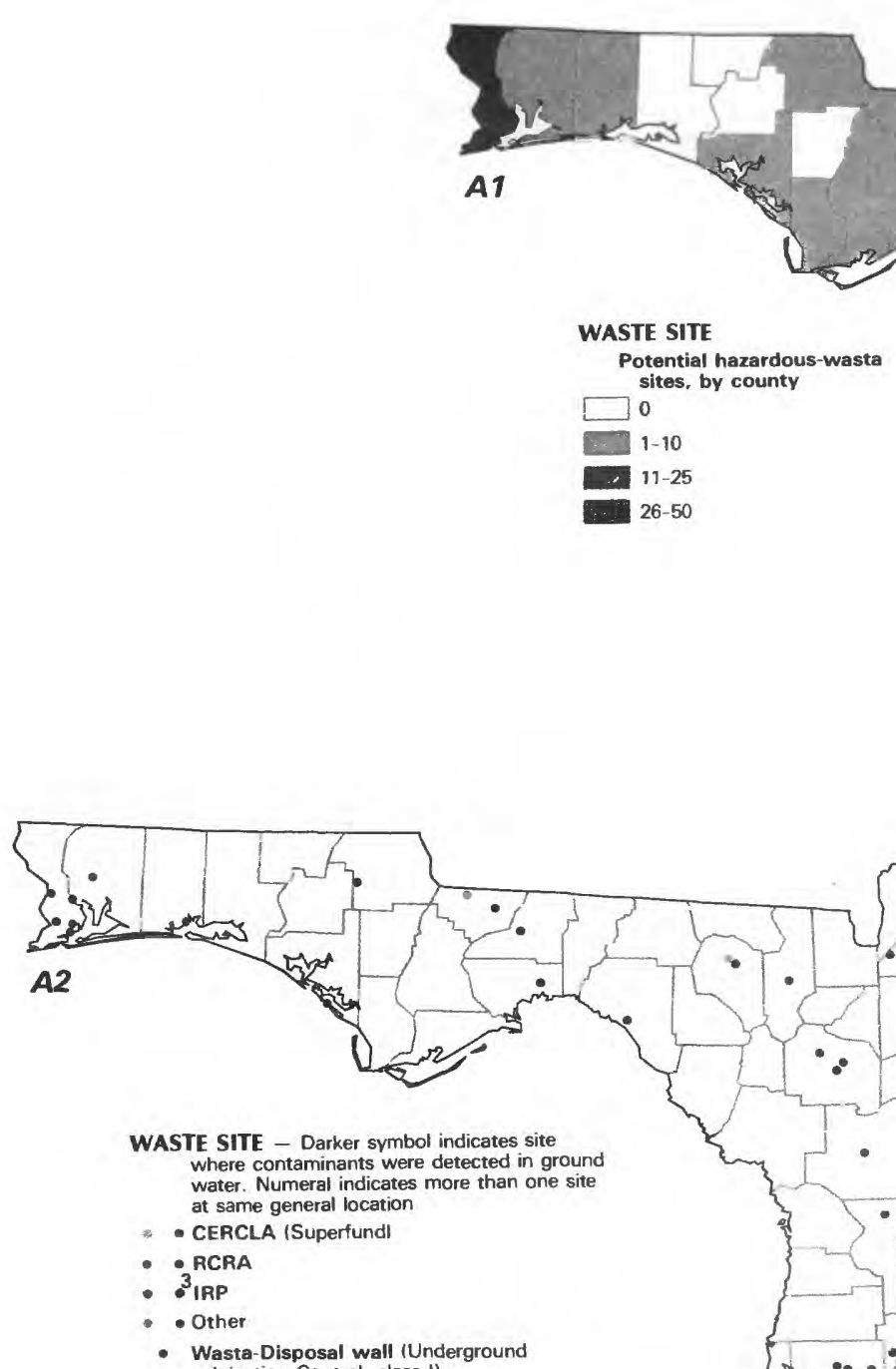
Injection Control, class ")
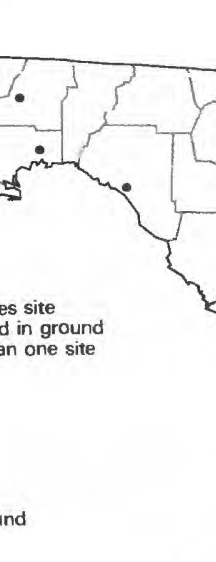


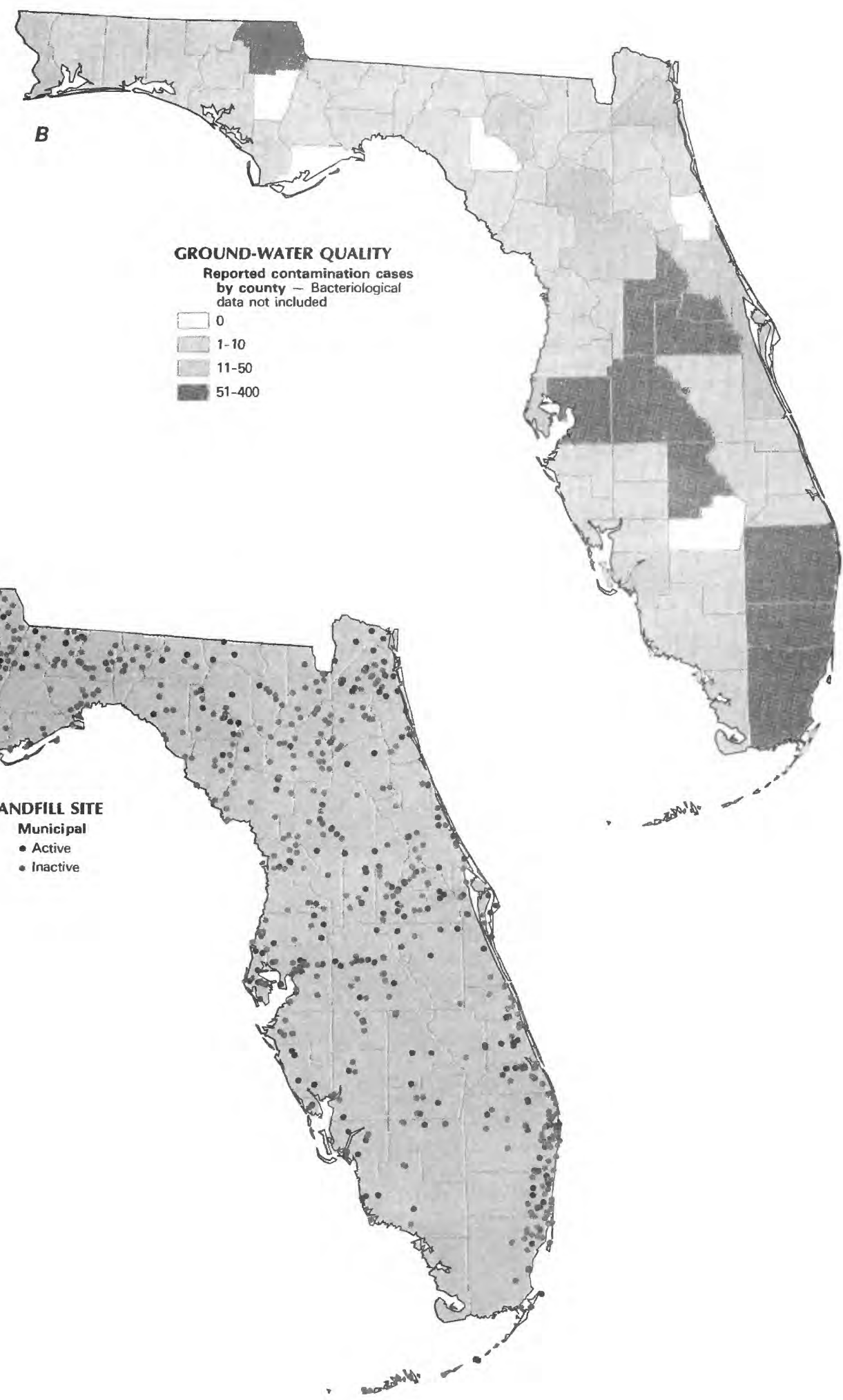

Figure 3.-Continued. 